\title{
IMPACT OF MICRO CREDIT PROGRAM ON SOCIAL MOBILITY OF WOMEN
}

\author{
Dilli R. Prasai \\ Lecturer, Sociology/Anthropology Department \\ PG Campus Biratnagar,Tribhuvan University Nepal \\ dilliprasai@yahoo.com
}

\begin{abstract}
The term development is defined various ways by different social scientist. For an example: Hugo Slim defines it, as "Development is not a commodity to be weighted or measured by gross national products. It is the process of change that enables to take changes of their own destinies and realize their full potential. It requires building up the confidence among the people. For this, the skill, assets and freedoms are necessary conditions to achieve this goal". The process of development crosses number of turns and bends as we see its historical tracks. Its starting point can be considered from mercantilism. The state led strategy is followed as an alternative option of mercantilism. Since the decade of 90, the community-based strategy has become one of the best options. In the later day, the NGO-led strategy is also standing as a strong alternative option in the development arena. It is quite impossible to distinctly differentiate the strategy wise policy of any government but the development by mobilizing the NGO came to be indispensable in the present world. The involvement of the women fluctuates in its dimension. At present, the government/donors and some INGOs and the women-specific National-level NGOs have moved faster to the development adopting gender approach-GAD. Other civil society institutions such as media and trade unions, local NGOs seem still to be grappling with the WAD approach.
\end{abstract}

\section{Key Words : Development, Micro-credit, Women}

\section{Background}

Since 1975 women were declared as an issue in development recognizing their role in production. But still today, as an impact of capitalistic production system, certain group seems outside the system. Women's involvement was seen as necessary for success of development projects not only in education and health but also in areas where they predominated as workers, particularly in agriculture and allied spheres in developing countries. Integration of women in the development process is a catchword. The financial sector therefore could not be the exception. Moreover, the distinguishing feature of the Beijing Platform as compared to earlier programs was its emphasis on the multi-dimensional nature of women's subordination and the need to attack it in all spheres by mainstreaming and empowerment of women which help to improve the social mobility of women.

As the disparity between men and women recognizes poverty alleviation is considered as a central point of the Tenth Fifth-Year Plan of Nepal. The gender mainstreaming has been emphasized since Eight Fifth-Year Plan in the national development process. It states that the objective of women and development shall be encourage active participation of women in various development activities. To enhance their accessibility to potential economic and social sectors and in order to make such access effective different efforts has been practicing by the different sectors. It responds to the recognition that mainstreaming gender equity is critical to ensuring women's contributions to public policy formation and the decision-making process. Women's poverty is reflected and maintained by their relative marginalization from the decision-making process and their lack of access and control over resources. Also contributing to women's poverty is the existence of gender-bias in the collection of national census data and violations of their human rights. Consequently, women in Nepal suffer from discrimination in all spheres of life and 
at all levels . Although rural life is hard for man and woman in Nepal, rural women in Nepal work longer hours in a day and have a higher workload than men due to their double responsibility for reproductive and productive tasks.

Due to the patriarchal structure the society gives priority to the male child because he will earn the livelihood for the family and he will be responsible to take care of parents at the old age. So, his participation in decision making in the family affairs are felt necessary whereas the girl child is trained to carry out household jobs. The task of boys and girls are quite determined in Nepalese society. The boys have their father's works and seldom participate in the household tasks. Confidence and self-esteem are not cultivated during the socialization of girl children. Gentleness, sacrifice, unassertiveness and often-feminine qualities are encouraged in girl children. Decision making, ability of expression, opinion formation and assertion of their needs and interests are mostly discouraged. The girls are confined to the inside world of the home and lack of access to the outside world of information, knowledge and resources . A recent assessment of the major changes in women's lives in Nepal over the past decade has shown that despite higher rates of attainment of literacy, social mobility and awareness, women still remain confined to the roles prescribed by the traditions of Nepali society. Considering the poor situation of women in Nepal and the significance of the recommendations made by the Beijing plus Five the government felt necessary to take initiatives to streamline the women population in the area of development by improving their overall situation. Thus, the study of impact of saving and credit program and its achievement in light of social mobility of women is beneficial. (Benedicte, 2009:103)

\subsection{Emergence of Women and Development}

In 1779 the English Woman Mary Wood Stone Craft was the first woman who had raised the first voice from the west for the social, political and economic equality of women. After this a meeting of five American women was held in 1884 in New York which is the foundation of women's rights convention. This was the first step towards women's suffrage movement in the USA. Thus, it laid down the foundation of the women's suffrage movement in the western world

In 1869 " The National Women Suffrage Association" was formed in the USA with the advent of 1890 both, those women's rights organization united into the "The National American Women Suffrage Association" for spreading up the voice, the first women's suffrage committee was formed in Britain in 1865. Women's suffrage committee has achieved goal in 1918

International Council of Women and International Women's Suffrage Alliance were formed in 1888 and in 1919 respectively. By the formation of these two international women's organization the women's movement took the international shape and thus it added new dimensions to it. Those two international women's organizations after their formulation started taking some actions for the betterment of the women's conditions including the rights of women of the world

The UN has been taking a leading role in the international arena regarding the advocacy for women's equality and rights. The first step taken in this direction was in 1946 when the UN commission on the status of women was formed to monitor the situation of women and promote women's rights around the world. Despite various attempts to eliminate any discrimination against women nonetheless continues to exist especially in poverty situations.

Nepal also could not remain unaffected by the wind of world concerns over women's issues and problems. It participated in all the world conference on women, and supported UN resolutions on such issue. Accordingly Nepal also rectified the 1979 UN convention on the elimination of all forms of discrimination against women. 
Further, to accelerate the women involvement, UN national general assembly declared (19761985) a" UN decade for women". The UN convention of the third world conference adopted the "forward looking strategies for the advancement of women to the year 2000" (NFLS) intended to provide a practical and effective guidance for the global action or a long term basic and within the context of the broader goals and objectives of a new international economic order and review in Beijing Conference 1995 .(Tuladhar,1994:67)

\section{METHODOLOGY}

Methodology is necessary for any research work. The research focuses the overall aspect and limitation of the present issues. It explains the procedure of the study from beginning i.e. selection of the study area to the end i.e. analysis of the data and presentation. It includes research design, nature of data, sampling procedure, data collection techniques use for the study. It also defines some variables and terms used in the present study. Both qualitative as well as quantitative types of data have been used in this study. Similarly, the primary and secondary data have been used, but most of the data uses for this study are primary in nature to make more effective and authentic. The data collection through various techniques in the field have been analysed descriptively. The checklist has also used to verify and to confirm the information provided by informants. The presentation of qualitative information in tabulated form has been carried out by using simple mathematical tools

\section{Major Findings}

\section{Level of Perception}

Particularly in the rural area of the country women education is not regarded as major concern though nation has been paying a lot of effort for the same. Because of this the women literacy rate is far lower than man. How the respondents in the study area perceived the importance of the education is consider as a factor to check the level of the awareness. The perception of the respondent is explored knowing their views on the implication of the education. Education is helpful to make women wise, it will create good opportunity of job, it will make them famous, it is helpful for searching good husband and it make women self-help are given possible options. In this regard, all respondents in the study area seem strongly positive especially in the command area. The cause to be so was also explored. It varied on the respondents wise. The meaning of education in case of command units seem to be self-help acquiring the job improving their qualification. But in case of the control unit the impression of the patriarchy is clearly remarked. In case of command area, out of 53 respondents 15 (28.30\%) in favor to be wise, 7(13.21\%) goes for better marriage and $8(15.09 \%)$ goes for to be famous, $36(67.93 \%)$ viewed for good job and $40(75.47 \%)$ goes to be self-help. In the control area, out of the 46 respondents $13(28.30 \%)$ in favor to be wise, 17(37.00 \%) goes for better marriage and $18(39.10 \%)$ goes for to be famous. The view of the respondent on that matter is depicted in Table 1 .

Table 1: Need of Education \& View of Respondents, multiple response

\begin{tabular}{|l|l|l|l|l|l|}
\multicolumn{2}{|c}{ S. N. } & \multirow{2}{*}{ Education is Required } & \multicolumn{2}{c}{ Command } & \multicolumn{2}{c}{$\begin{array}{c}\text { Control } \\
\text { Command Unit }\end{array}$} \\
\cline { 3 - 7 } & & $\begin{array}{c}\text { Number of } \\
\text { Respondent }\end{array}$ & $\begin{array}{c}\% \text { of } \\
\text { Total }\end{array}$ & $\begin{array}{c}\text { Number of } \\
\text { Respondent }\end{array}$ & $\begin{array}{c}\% \text { of } \\
\text { Total }\end{array}$ \\
\hline 1 & To be Wise & 15 & 28.30 & 13 & 28.30 \\
\hline 2 & For Good Job & 36 & 67.93 & 21 & 45.70 \\
\hline 3 & To be Famous & 8 & 15.09 & 18 & 39.10 \\
\hline 4 & For the Better Marriage & 7 & 13.21 & 17 & 37.00 \\
\hline
\end{tabular}




\begin{tabular}{|c|c|c|c|c|c|}
\hline 5 & To be self Help & 40 & 75.47 & 25 & 54.30 \\
\hline \multicolumn{6}{|c|}{ Source: Field Survey, 2012} \\
\hline
\end{tabular}

Table 1 . disclosed that with regard to the importance of the education, the view of the respondents in the control area is different with view of the respondents in the command area. Observing the above figure, it can be clearly judge that the opinions of the women in the command area are far above from the patriarchy feeling. Whereas, the views of the women in the control area are seen backward, frustrate, and innocent. Even in the changing context they are not changed realizing their roles and responsibility as in the command area. Thus, from the analysis it is realized that the financial activities along with other mention capacity building programme has changed sufficiently the status of women realizing their inherent capacity of the respondent in the command area. Finally, from this analysis at least the readiness to move from the present position to new dimensions is known.

\section{Perception on Role given by the society}

To analyze the level of awareness about social role of women the degree of satisfaction to the role of women given by society is considered. On the basis of these factor how they perceived their role, to what extent the programme became successful to intervene them with regard to awareness are known with this analysis. The result is depicted in Table 2.

Table 2 View of Respondent on Role of Women Given by Society

\begin{tabular}{|c|c|c|c|c|c|}
\hline \multirow{2}{*}{ S. N. } & \multirow{2}{*}{$\begin{array}{l}\text { Role Given by } \\
\text { Society Satisfaction }\end{array}$} & \multicolumn{2}{|c|}{ Command Unit } & \multicolumn{2}{|l|}{ Control Unit } \\
\hline & & $\begin{array}{l}\text { Number of } \\
\text { Respondent }\end{array}$ & $\begin{array}{l}\% \text { of } \\
\text { Total }\end{array}$ & $\begin{array}{l}\text { Number of } \\
\text { Respondent }\end{array}$ & $\%$ of Total \\
\hline 1 & Satisfied & 4 & 7.55 & 9 & 19.57 \\
\hline 2 & Normal & 7 & 13.21 & 12 & 26.09 \\
\hline 3 & Unsatisfied & 27 & 50.94 & 16 & 34.78 \\
\hline \multirow[t]{2}{*}{4} & Strongly Unsatisfied & 15 & 28.30 & 9 & 19.57 \\
\hline & Total & 53 & 100.00 & 46 & 100.00 \\
\hline
\end{tabular}

Source: Field Survey, 2012

Out of 53 respondents only 4 (7. 55\%) in the command area are satisfied but $9(19.57 \%)$ respondents out of 46 in the control area are found satisfied with the women role given by the society. This fact proves that the women of the programme area are more consensuses comparing with the women of the control area. The independent source of income involving in team irrespective of its size exposed them to new sets of ideas, value and social support. Because of this women of the programme area comparing with the non-programme area became more assertive of their right. Moreover, women of programme area have better understating because study sows that about $51 \%$ of respondent express dissatisfaction with present role given by the society. Due to training programme, interaction among themselves, sharing the view, excursion tour, and continue involvement in the programme activities make them aware. The respondent opined that as per the work division, they have to perform more work within the household. They generally considered as a second type of citizen. One of the strong reasons is religious boundary. These factors may be the cause of the satisfaction with the given role to women in the nonprogramme area. It is concluded that the status of women in the programme area moves up in comparison to the women of non-programme area. To improve the mobility of women in the nonprogramme area similar type of saving and credit programme has to be extended with the proper awareness programme. 


\section{Perception of women on legal provision}

The legal issue, in addition, is also selected to test the women's level of knowledge. Numbers of legal provision have been formulating in the country to safeguard the women situation. Women and Property Right Rule, Rule Against the Women Trafficking, Women and Civil Code, The Child Labor Prohibition and Control Bill, Reproductive Right, Inheritance Right etc. are some of the example of prevailing legal provision to safeguard the women situation in Nepal. This provision would be familiar to the every women of county even in the rural area. But this may not be the present situation. Therefore, it is consider the one of the indicator to test the status of the women in the study. To test the level of knowledge of women the question was asked whether they are familiar for at least any one of the legal provisions formulated to safeguard the women or not. If any respondent is familiar for any one then it is assume that she is knowledgeable to the legal provision.

Table 3 Knowledge on Legal Provision

\begin{tabular}{|c|c|c|c|c|c|}
\hline \multirow{2}{*}{$\begin{array}{l}\text { S. } \\
\text { N. }\end{array}$} & \multirow{2}{*}{$\begin{array}{l}\text { Do You Know about } \\
\text { Legal Provision } \\
\text { formulated for The } \\
\text { welfare of Women? }\end{array}$} & \multicolumn{2}{|l|}{ Command } & \multicolumn{2}{|l|}{ Control } \\
\hline & & $\begin{array}{l}\text { Number of } \\
\text { Respondent }\end{array}$ & $\begin{array}{l}\% \text { of } \\
\text { Total }\end{array}$ & $\begin{array}{l}\text { Number of } \\
\text { Respondent }\end{array}$ & $\begin{array}{l}\% \text { of } \\
\text { Total }\end{array}$ \\
\hline 1 & Yes & 38 & 71.70 & 17 & 36.96 \\
\hline 2 & No & 15 & 28.30 & 29 & 63.04 \\
\hline & Total & 53 & 100.00 & 46 & 100.00 \\
\hline
\end{tabular}

Above table revealed that only 17(36.96\%) out of 46 of women respondent are knowledgeable in the non-programme area on the considered issue. The level of knowledge of women in the programme area is $71.7 \%$, which is far higher than non-programme area. Therefore, the studies conclude that the status of women is changed sufficiently by the project intervention. The training, as a capacity building programme, interaction sharing of views and ideas among the team member and dissemination of the message from outsider help to improve the level of knowledge seems important. Thus, the analysis disclosed that the programme of GOs and NGOs is meaning full and beneficial for the women's horizontal and vertical mobility in the society.

\section{Women Involvement in Different Household Activities}

Rural women in Nepal work longer hours than man. Their contribution is not evaluating to the require extent. Through the gender mainstreaming programme the involvement of the women is being ensured in the policy formulation and decision making process. The status of the women from survival to autonomy being security is track of mobility. Regarding women mobility in developing country like Nepal is just above the threshold level. The utilization of all indicators may be in vain in this study. Therefore, to explore the status of women in the context of involvement in decision making process within the household burrowing \& investment of money, management of livestock, selling \& buying of goods, issues of family planning agricultural activities and, selling \& buying land are considered factors to assess the level of decision making. Out of number of factors, mention factors were finalized on the basis of pretest of the questionnaire because these activities are very common within the household in the study area. The replies of the respondents are presented in Table 4.. From table, in case of command area, out of 53 respondents $23(43.30 \%)$ in burrowing and investment of money, $45(84.91 \%)$ in managing livestock, $43(81.13 \%)$ in goods selling \& buying, 33(62.26 \%) in issues of family 
planning, $45(84.91 \%)$ in agricultural activities, and 12(22.64\%) in selling \& buying land are involved.

Table 4. Involvement of the Women in the Decision Making

\begin{tabular}{|c|l|r|r|r|r|}
\hline \multirow{2}{*}{$\begin{array}{c}\text { S.N } \\
\cdot\end{array}$} & Involved in the Activities of & \multicolumn{3}{|c|}{ Command } & \multicolumn{2}{|c|}{ Control } \\
\cline { 3 - 7 } & $\begin{array}{c}\text { Number of } \\
\text { Respondent }\end{array}$ & $\begin{array}{l}\% \text { of } \\
\text { Total }\end{array}$ & $\begin{array}{c}\text { Number of } \\
\text { Respondent }\end{array}$ & $\begin{array}{l}\% \text { of } \\
\text { Total }\end{array}$ \\
\hline 1 & Burrowing \& Investment of & 23 & 43.40 & 14 & 30.43 \\
\hline 2 & Money & 45 & 84.91 & 24 & 52.17 \\
\hline 3 & Ganagement of Livestock & 43 & 81.13 & 21 & 45.65 \\
\hline 4 & Issues of Family Planning & 33 & 62.26 & 27 & 58.70 \\
\hline 5 & Agricultural Activities & 45 & 84.91 & 17 & 36.96 \\
\hline 6 & Selling \& Buying Land & 12 & 22.64 & 9 & 19.57 \\
\hline
\end{tabular}

Multiple Response

Due to intervention of the programme, in totality, the women involvement is remarkably higher in the programme area than in the control area. The reason of higher percentage of involvement may be due to the empowerment of the women. The saving and handling of the money along with training and their involvement in outdoors activities make them so.

\section{Involvement of Women in the Outdoors Activities}

Basically, involvement of women is limited within the household level. Caring of child, cooking and washing, working in the field etc. are some of the example of the nonproductive activities. In present changing context the involvement of women also changing. In this study, to assess the women mobility marketing, health care, paying bill, meeting and participation in the procession are identified factors. The women's view is collected by means of question 'what are the out door activities you involve in?' The answer of the respondents is summarized in Table 5

Table 5. Women Involvement in Outdoors Activities Multiple response

Total

Responde

Total

\begin{tabular}{|c|l|c|c|c|r|}
\hline \multirow{2}{*}{ S. N. } & \multirow{2}{*}{$\begin{array}{l}\text { What for has you gone } \\
\text { outside your premises? }\end{array}$} & \multicolumn{2}{|c|}{$\begin{array}{l}\text { Respondents } \\
\text { Command }\end{array}$} \\
\cline { 3 - 6 } & & $\begin{array}{l}\text { Number of } \\
\text { Respondent }\end{array}$ & $\begin{array}{l}\text { \% of } \\
\text { Total }\end{array}$ & $\begin{array}{l}\text { Number of } \\
\text { Responden } \\
\text { t }\end{array}$ & \% of Total \\
\hline 1 & Marketing & 23 & 43.40 & 16 & 34.78 \\
\hline 2 & Health Care & 7 & 13.21 & 5 & 10.87 \\
\hline 3 & To pay bill etc & 28 & 52.83 & 8 & 17.39 \\
\hline 4 & Meeting & 35 & 66.04 & 3 & 6.52 \\
\hline 5 & Procession & 13 & 24.53 & 2 & 4.35 \\
\hline
\end{tabular}

Source:- Field Survey, 2012

Out of 53 respondents the involvement of women in marketing, paying the bill, meeting, and procession are $43.4,52.83,66.04$, and $24.53 \%$ respectively in the command area. In the control area the percentage of women involvement in these identified factors is sufficiently low. The Table 5.7 disclose that the involvement of women in the outdoors activities is higher in the 
command area comparing with the non-programme area. Previously the women activities were limited within their premises. Herein too, the participation of women in the out-of-doors activities is near to the ground. The various programme conducted in the community induce them to participate in out-of-doors activities. The external agencies organized different awareness creating activities like: training programme, meeting, excursion tour, rally, procession, mass meeting etc. Due to the organization of this kind of programme women, even from the backward area, became active. They were found capable for putting their view even in front of big and unfamiliar mass. On the discussion at the household level, most of women from the programme area opined that they learned a lot of things- learned to talk, learn to deal with other people etc. in course of involvement in NGO/GO's programme. The woman from the non-programme area seems very pessimistic. On the discussion they said that being women they are not liable to perform any activities as of man. In contrary, the women from the programme area said that they could perform any types of work as better as man. It can be said that the level of confidence within the women of the programme area is definitively improved due to the activities of saving and credit programme. In the group discussion, women political actors opined that their in this kind of involvement make comfortable in dealing within their parties' activities. Finally, the social mobility of this kind is as a result of programme intervention.

\section{Level of Women Participation}

As per the participation perception women's equal participation is emphasized in the decisionmaking, policy-making, planning process, project and administration. It is mainly related to the development project work where women involvement is stress in project selection, implementation, monitoring and evaluation. If the women are equally involved in this process is considered as a women empowerment. The participation of women is made mandatory in policy level. Its assessment in practice is relevant to study though the participation of all this kind is not possible to consider. In the study, therefore, the involvement of women in the user committee of any development project is considered for the analysis. Figure 1.

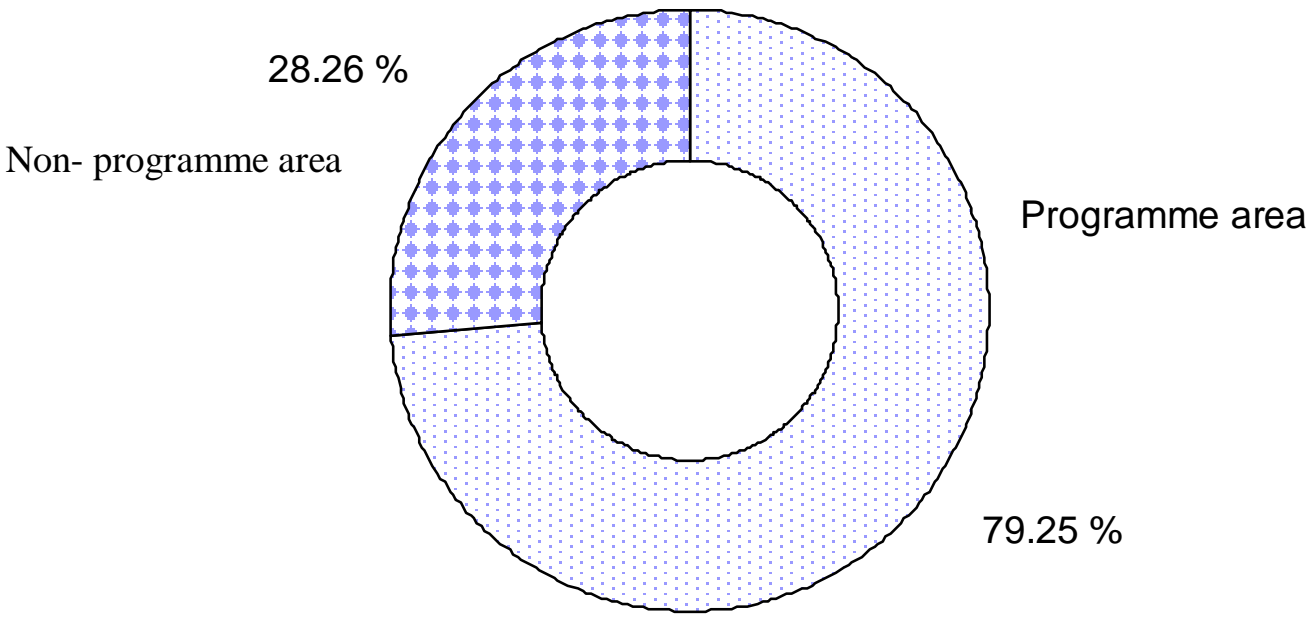

Figure 1 Women Participation in Social Organization

Out of 53 respondent $42(79.25 \%)$ in the programme area are participated in the social organization. But incase of non-programme the level participation is only $28.26 \%$. This analysis disclosed that women participation in development activities is far low in non-programme area. The regular meeting, time-to-time visit beyond household premises, sharing and exchanging the views among other, training and amount of collected money etc. helps to expose women in the society improving level of participation. On the discussion with women group in the study area 
express their views confidently in this regard. Though, substantial involvement in secretariat post is not found even in the programme area. However, the compulsory participation of women develops the leadership quality in the society. Finally, it helps to improve the mobility of women in the society to some extent.

\section{Conclusion}

From the study following conclusion are drawn

- Women can realize their inherent capability; it is sue to the implementation of micro credit with awareness and capacity building programme.

- The perception power of the women is changed sufficiently by the programme intervention because women appeared ready and interested to overcome socially given roles;

- The technical assistance for capacity building is necessary to accelerate the effectiveness of the programme;

- By the generation of regular source of income outside home, micro credit tends to reduce dependency of the women economically on their husband;

- Along with source of income their exposure to new sets of ideas, value and social support should make these women more assertive of their right;

- Women's prestige and status in the eye of husband and neighbors should promote intersperse consultation by micro credit programme

- As a result of programme, income fetching economic activities like: - Agriculture, business, livestock keeping etc. are improved creating a money making avenues influencing the rate of social mobility in its magnitude and effects.

\section{Reference}

1. Achrya Balaram ( 2003). Analysis of Nepali Society and Culture:Kathmandu: Bidharthi Prakashan,

2. Acharya Meena ( 2001). Women and the Economy: The Key Issues, Gender and Democracy in Nepal : Kathmandu :CEDA

3. Acharaya, Meena and Pushpa Acharya (1997) Gender Equality and Empowerment of Women. A Status Report, UNEPA, Kathmandu.

4. ADB Program Department West Division 1, Women in Nepal, Country Paper, December 1999

5. ADB, Gender and Development: Rural Micro Finance Project, 2012

6. Benedicte, Lie(1999). Born to be a Butcher? A Study of Social Mobility and Symbolic Struggles of Low Castes in the Kathmandu Valley

7. Bennett, Lynn(1993) Dangerous Wives and Sacred Sisters, , Columbia University Press, New York.

8. Bhattachan, KB (1998). Understanding of Women. The Rising Nepal, November 6

9. Kothari, C.R.( 2004). Research Methodology Method \& Technique. India : Sage Publication

10. LIDS, 2010 Improving Assess of Women to Formal Credit Facilities in Kathmandu, Nepal

11. UNDP (MEGEP),2011. Women and economy :Kathmandu

12. Tuladhar, Jyoti (1994). Role of the Women in the Nepalese Economy. Kathmandu National Planning Commission Population Division/CWD 